Esta publicación cientifica en formato digital es continuidad de la revista impresa ISSN-Versión Impresa 0798-1406 / ISSN-Versión on line 2542-3185Depósito legal pp
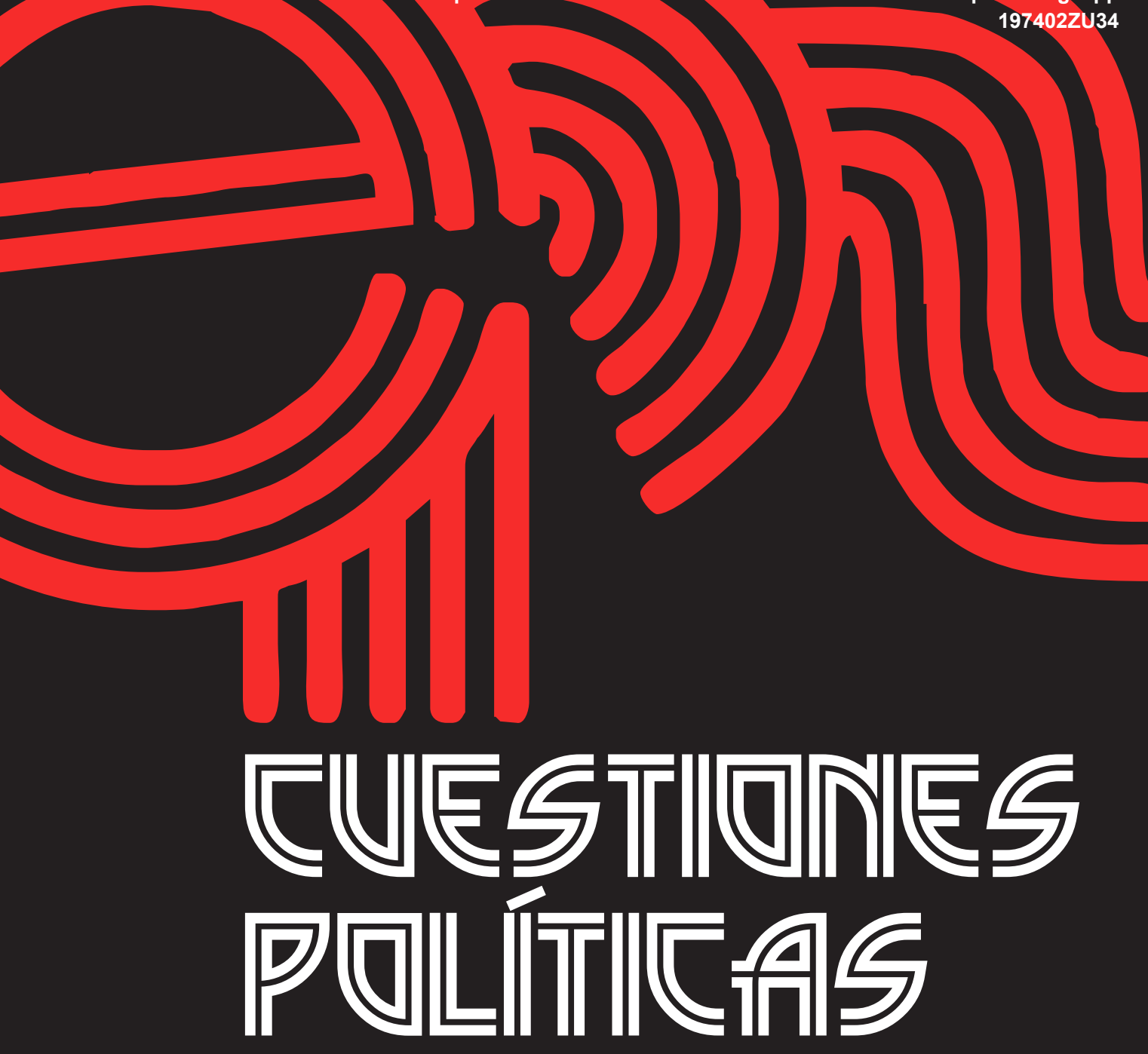

Instituto de Estudios Políticos y Derecho Público "Dr. Humberto J. La Roche" de la Facultad de Ciencias Jurídicas y Políticas de la Universidad del Zulia Maracaibo, Venezuela
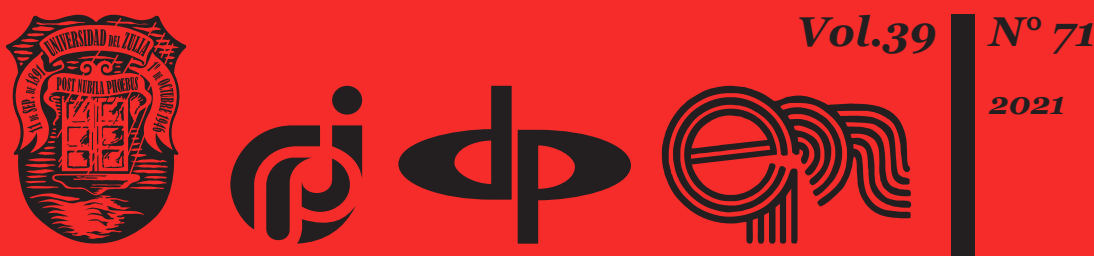


\title{
The Relationship Between the Right to Security and the Right to Freedom in Islam and the Study of Formal Rules for Relinquishing these Rights in Iran
}

\author{
DOI: https://doi.org/10.46398/cuestpol.3971.47
}

\author{
Saeed Ayoobi Yazdi * \\ Seyed Mehdi Mansouri ** \\ Mohammad Reza Rahmat ***
}

\begin{abstract}
This article raises fundamental conceptual questions about the relationship between the right to security and freedom, from the point of view of Islam. Also, in criminal law in Iran, the relationship between freedom and security is examined in all formal laws adopted after the Iranian Revolution. This study was conducted with a descriptive-analytical method using sources and documentary texts with the aim of explaining the relationship between the right to security and freedom in Islam and, at the same time, analyzing the formal rules of renunciation of these rights in formal laws and regulations. It is concluded that in Islam three types of minima, intermediate and maximum relations between security and freedom are conceivable. These three proportions, in addition to fulfilling the existence of security and freedom; introduce different types of relations between the two rights referred to according to the conditions that can be implemented. Likewise, when examining the formal norms, it can be recognized that the Code of Criminal Procedure, approved on 23.02.2014, has eliminated all the defects and ambiguities of the previous law in the field of the right of persons to
\end{abstract} liberty and personal security.

Keywords: right to security; right to freedom; legal relations; formal rules; iranian criminal law.

PhD Student in Law, Faculty of Humanities, Islamic Azad University, Yazd, Iran. ORCID ID: https:// orcid.org/o0oo-0002-7212-9482

** Assistant Professor of Law, Faculty of Humanities, Islamic Azad University, Yazd, Iran. ORCID ID: https://orcid.org/oooo-0002-8769-3959 (Corresponding Author).

*** Assistant professor of Law, Faculty of Law, Meybod University, Meybod, Iran. ORCID ID: https:// orcid.org/oooo-0003-4434-6954 


\section{La relación entre el derecho a la seguridad y el derecho a la libertad en el islam y el estudio de las reglas formales} para renunciar a estos derechos en Irán

\section{Resumen}

En el presente artículo se plantean cuestiones conceptuales fundamentales sobre la relación entre el derecho a la seguridad y a la libertad, desde el punto de vista del islam. También en el derecho penal en Irán, se examina las relaciones entre libertad y seguridad en todas las leyes formales adoptadas después de Revolución iraní. Este estudio se realizó con un método descriptivo-analítico utilizando fuentes y textos documentales con el objetivo de explicar la relación entre el derecho a la seguridad y la libertad en el islam y, al mismo tiempo, analizar las reglas formales de renuncia a estos derechos en las leyes y regulaciones formales. Se concluye que en el islam son concebibles tres tipos de relaciones mínimas, intermedias y máximas, entre seguridad y libertad. Estas tres proporciones, además de cumplir la existencia de seguridad y libertad; introducen diferentes tipos de relaciones entre los dos derechos referidos según las condiciones que se pueden implementar. Asimismo, al examinar las normas formales, se puede reconocer que el Código Procesal Penal, aprobado el 23.02.2014, ha eliminado todos los defectos y ambigüedades de la ley anterior en el campo del derecho de las personas a la libertad y seguridad personal.

Palabras clave: derecho a la seguridad; derecho a la libertad; relaciones jurídicas; normas formales; derecho penal iraní.

\section{Introduction}

Security is the absenteeism of psychological and physical threat to the individual and society. If freedom has been the voice of man for many centuries, it can be said that security has been the equal desire of man and animal in all times and places. The quest for security is based on human nature, and apart from the fact that security is the necessity of social life or the establishment of the state; but from the very beginning of creation, it has always been one of the desires of human beings. But when "security" comes into society, it has a more advanced meaning because, from an individual point of view, security includes the protection of rights and freedoms and human security in providing the necessary conditions for human health, but from a social point of view, in Friedman, view. "Security in the objective sense determines the absence of threat against the acquired values and in the mental sense determines the fear of attacking the values" (Friedman, 1999: 246). This is where national security and international security come into play to preserve these values. 
In the modern sense of security, we also speak of the security of the dependencies of human life, which are inanimate things; including money security, cyberspace security and communication network security; "The idea of security can be applied to comfortable objects of people" (Buzan and Weaver, 2007: 79).

For example, the security of money in a bank is subject to calculations related to certain threats in terms of its unauthorized relocation or the possibility of the effects of inflation on value. But the security of individuals cannot be simply defined. Factors such as life, wealth, social status, health, and freedom are very complex and many of them are irreplaceable in case of loss (Dinarvand et al., 2021).

Now, considering broad meaning of word and its similarity can be less found in other words, it is necessary to know its characteristics in order to gain a more accurate understanding in examining the relationship between this concept and freedom. In total, there are two characteristics of security that open the way for governments to always prioritize security over freedom in "emergencies" (Forouzan Far, 2021).

First, security is inherent. Man is equal to animals in his pursuit of security, and apart from how and to what extent, they both escape threat and insecurity, while this cannot be claimed with respect to freedom, and it is only man who seeks freedom; Because "if a creature does not have intellect, freedom and lack of freedom are the same for him" (Soroush, 1992: 59). But security is rooted in the course of human life. Although human beings have realized for thousands of years that the secret of their survival is collective life and the instituting of the state, but much later they sought to gain freedoms and rights. This shows that the first human need is security, not freedom (Soroush, 2009).

\section{Recognizing the Concept}

In any scientific research, it is necessary to first discuss the concepts and definitions of the key words of the research. In the present study, we first try to address this issue and examine the two main concepts of this paper, which are "security" and "freedom".

\subsection{The concept of security}

Humans and animals, both in terms of inner perception, always avoid external threats and therefore turn to collective life for their survival. This collective life brings some security, but it does not eliminate insecurity. To avoid insecurity in social life, here the human path is separated from the animal and, from wisdom; he establishes a system of domination and 
obedience, the result of which is the establishment of the state. The tendency towards security and the establishment of a government to protect it; It has both a sociological and a psychological face.

The sociological approach to security was developed by Mirahmadi, considers security as the reason for the establishment of the government and its end. He writes in Leviathan:

The ultimate goal, purpose and desire of human beings (who naturally love freedom and domination over others) is to restrict themselves (which is to live within the state), to be far-sighted about self-preservation and to Consequently, providing a more satisfying life (Mirahmadi, 2012: 113).

In Shakeri, viewpoint, natural laws such as justice, fairness, moderation, compassion, and doing what we do not like about ourselves towards others can in no way guarantee human security (Shakeri, 2006).

So, despite the natural laws, if not enough power is established to ensure our security, then everyone can and will really rely on their own power and skill to be cautious in front of others, and wherever people are within the dynasty, small tribes and clans have lived, looting and plundering each other has become a work and profession and has never been considered contrary to the law of nature (Mirahmadi, 2012).

In Shakeri, viewpoint, security does not come from the unity of groups, no matter how many. Even if these groups come to power at critical times when security is threatened, such as war, they still do not achieve security. The only way to obtain and maintain security:

That can protect people from the invasion of strangers and from each other's harms and protect them so that they can nourish themselves through their own efforts and through the fruits of their land and live well and happily. It is to delegate all their power and authority to one person or group of people (Shakeri, 2006: 748)

Indeed, this has always been the case to this day, so the government is considered as the framework and system of social life, whose essence protects both individual security and social security (Shakeri, 2006).

The psychological approach to security is that of Earth Friedman, in his view man has felt lonely and insecure no matter how much he steps towards freedom. The more man is freed from the bondage of primitive oneness with other people and nature, and the more he finds himself, the more he will find himself faced with the choice that he is compelled to surrender himself to love and productive work and thus unite with the world or pursue a kind of safety that is the product of dependencies on the world that do nothing but destroy freedom and self-righteousness (Friedman, 1999).

Mirahmadi, contrasts individuality with security, saying, as long as one is a complementary part of this world and unaware of one's possibilities and responsibilities, there is no need to be afraid of it. But when one finds 
individuality, one must stand alone against the world and its dangerous and powerful aspects (Mirahmadi, 2012).

According to Mirahmadi, to achieve security and escape from freedom, "there are two main ways in society: in fascist countries, submission to a leader and in democracy, obsession to be with others" (Mirahmadi, 2012: 113).

That is, one of the fundamental roots of fascism in Germany was security-orientation, and the German people accepted this security, even though it was accompanied by Nazi dictatorship. Mirahmadi, considers this simultaneous tendency of the Nazis and the German people to be close to the sadistic and masochistic tendencies:

Sadism means the desire for unlimited power over someone else, and this desire is sometimes mixed with a sense of destruction. Masochism means the desire to change to the powerful power and to share in its power and glory. Both sadistic and masochistic talents are both the result of the single person's inability to bear loneliness and his need for a coexistence that overcomes this loneliness (Mirahmadi, 2012: 113).

Secondly, security has a contractual aspect. Being contractual is in long with being natural of security. Here security is limited not only to man but also to society. In fact, the establishment of the state always expresses a meaning of security that is related to sovereignty (power). In this sense, "the contract is the footstone of security. With the institutionalization of the contract, the power of establishment and security is provided and maintained" (Shakeri, 2006: 748). If we express power and security in two scales, the fulcrum that determines the balance of power and security is the contract. According to Hobbes, power can guarantee security when it is the product of a contract. The power of an individual who is not bound by a contract conflict with security, and personal power is always considered a threat to security (Shakeri, 2006).

\subsection{Recognizing the Concept of freedom}

Ashour, has a broad and general meaning, and at first sight it refers to the situation of a person who is not a deterrent to his actions, words, and thoughts. The meaning of this word is close to the meaning of the two words authority and will, and since all three of these words are relative and general, no clear boundary can be drawn between them.

The first meaning of freedom must be examined from a religious point of view, on the basis of which man is created free and independent, and some thinkers have put the manifestation of freedom at the forefront of creation and mentioned the devil's disobedience to God's command as the fundamental origin of freedom; After the expulsion of the devil from the court of God, he swears to mislead man, and this "presence and action of 
devil on man as a force or opposite pole to the instinctual force of creation and reason and expediency, leave us in temptation and confusion; That is, it amazes and confuses us" (Ashouri, 2008: 40).

This is the same authority, freedom, position, and gift that God has given to mankind. From the point of view of divine rituals, freedom begins with the choice of the devil or God, and the freedom and slavery of man follows which one he chooses. It is clear that going to God is freedom from the bondage of the devil. Such freedom cannot be neglected; since one of the fundamental reasons for the liberation was the chains that religious rulers and leaders were tied to human feet. They used the pretext of religion or the fattening of its precepts to try to enter the most hidden parts of human life and lead them in a way they love. That is, the desire for liberty in Europe began with enmity with the church (Ashouri, 2008).

The religious view of freedom marginalizes man and seeks obedience and servitude only from it, and philosophers and thinkers saw that religious rulers and powerful people sat in the place of God and took man to a third path between God and the devil which ended on their own, and to escape from this vast trap, they put forward philosophical and legal freedom, focusing on man himself.

From a philosophical point of view, various views have been put forward due to the ambiguity of the position of freedom or authority. The first question of thinkers in this field is whether the existence of freedom or free will is necessary or whether freedom is based on the link of causality? Leibniz seeks to establish a place for freedom by distinguishing between absolute necessity and probable necessity by turning to destiny. The action of substance relies on the necessity of God's decision on which the existence is on its basis, but it is possible. It means that it is practiced freely. Therefore, determining the essence is not practical, but is an increasingly continuous tendency towards what will happen and what will not happen (Hatzenberger, 2007).

Kant also considers the autonomy of the will as the highest principle of morality and the only principle of all moral laws and duties of confrontation. If there is no freedom, one can neither learn from moral behavior and authority to follow or disobey the law, nor from the possibility of the absolute. In his view, "there is only one absolute thing, and that is to act only on that rule by which you can at the same time want this rule to become general" (Copleston, 2013: 141).

In contrast, utilitarian's do not believe in the originality of freedom. Hume, for example, takes the step of destroying freedom with the vision of belief. Although he separates free will or free will from the will in general, in any case, he considers free will or freedom (free will) as a means of rejecting necessity or accident. According to him, "necessity is the essential 
component of causality, and as a result, freedom, by removing necessity, also removes causes, and is exactly the same as accident" (Copleston, 2016: 173). Because it is often thought that accident requires contradiction and at least is directly opposite to experience, there are always the same arguments for rejecting free will.

For Hume, therefore, free behavior is behavior that has no cause; Because he recognized only one kind of causal relation in which it is to some extent a linguistic problem, that is, although freedom must be denied, it can be acknowledged if it is defined in such a way as to impede necessity, if it is defined in another way. For example, if freedom is taken with the same with spontaneity, there is freedom; because it is clear that many human actions arise as rational actors without external coercion to reject work. Indeed, spontaneity is the only form of freedom that we must strive to acknowledge (Copleston, 2016).

Ashouri, natural rights advocates see rights as pre-legal and the law as the only means of finding and enumerating rights as well as supporting them, in the end what is the criterion of right is that the law recognizes it as right and hence the origin of freedom is the law. The law configures freedom in two ways. The first is to predict the patterns of freedom and the second is to determine its size and boundaries. so it is the law that nurtures freedom and separates it from identical meanings such as chaos, selfishness, and permissiveness. Although the most prominent criterion of wise freedom is not to harm others, the same should be known of the law. Therefore, the background of freedoms should be sought in laws or documents.

International law and documents have never been involved in defining dynamic words such as justice, freedom, order, and security, but it is not clear how the proponents of the French Declaration of Human Rights and Citizenship of 1789 how have come to believe in the need to define freedom. Article 4 of this declaration states: "Freedom is the ability to do anything that does not harm others" (Ashouri, 2008: 40).

The idea of freedom is a Western product and not something that Europeans have learned from the East. The ground for freedom has been laid since the Enlightenment in Europe, and it has been reflected in the minds of philosophers of the continent, especially Britain, who are led by John Locke and John Stuart Mill. Among Muslim countries, most those who travel to foreign countries sought freedom, but the people and political power were neither able to accept it nor knew it well. In Iran, the idea of freedom was founded shortly before the constitutional event and was closely linked to this movement.

One of the origins of the constitution (as we will discuss in future discussions) has been the writings and speeches made by thinkers who travel to foreign countries about freedom. These ideas provided the bedrock 
of freedom in an Iran where traditionalism and religiosity were rampant. Also known as liberalism, constitutionalism places Iran at the forefront of countries that have strived for freedom and achieved great achievements such as legislation and conditional government.

\section{Methodology}

This research, which has been done in a descriptive-analytical method, using library sources and texts, with the aim of explaining the relationship between the right to security and freedom in Islam and analyzing the formal rules, deprives these rights in formal rules and regulations. Accordingly, the required information will be collected using the library method. For this purpose, the tool of taking notes and preparing a checklist will be used.

An attempt is made to accurately identify the available resources in the country, including law books related to the subject, articles and dissertations related to the discussion, as well as internal laws and regulations and, if necessary, Internet sites such as the Comprehensive Humanities Portal and Noor Islamic Studies Center after preparing a checklist and taking notes from the found sources, collected the information and then started the work of writing the article by logical analysis and summarizing the information.

\section{The relationship between security and freedom in Islam}

Considering that basically one of the most important sources of Iranian law is jurisprudence and the teachings of Islam, so in this section we will try to examine the situation and the relationship between security and freedom in Islamic societies, as well as its relationship in the Islamic system.

\subsection{Security and freedom in Islamic societies}

Based on Islamic criteria, a theory can be put forward according to which, in terms of substance and proof, there is basically no difference or conflict between individual and collective interests, and in fact, each is on two sides of the same coin. They complement each other. These rights, which have the same origin and purpose, are based on religious teachings based on human values and common rights such as justice and dignity, which are accepted by human society. But what may happen is not an inherent conflict or contrast of individual or collective interests, but an antagonism in their practical provision.

In other words, in terms of implementation, the operational scope of protection, provision and guarantee of individual or collective rights that have challenged criminal policy. In this way, according to the principles and 
religious teachings based on reason, narration, and revelation in a direction in the direction of logic, law and rationality will be able to eliminate the conflict. Recognition and preparatory study of this ratio requires acceptance of the assumptions, some of which are mentioned below.

\subsection{Assumptions}

Understanding the relationship between security and freedom in Islam requires several basic assumptions that are derived from religious teachings and accepted as assumptions.

\subsection{The ultimate goal}

The ultimate goal of any criminal strategy or policy that derives from Islamic teachings should be to "move towards pure light" which is the series of all causes and essence of the sublime and enlightenment and justice to the attributes and ultimately the provision of good human life and material and spiritual dimension in the light of Shari'a and rationality (verse 1 of Surah Ibrahim)

These concepts are very important and basic because they determine the destination and ultimately all actions and their direction. Other concepts such as security, justice and freedom are considered as mediators to achieve the ultimate goal.

\subsection{Intermediate goal}

In order to create the right balance between security and freedom, it is necessary to consider a kind of alignment between the mediating goals. Regarding this alignment, it should be emphasized that all intermediate goals should be the basis for achieving the ultimate goal and in their internal relations should not be conflicting or contradictory, but all of them should be assumed to complement each other, which means that justice is a better guarantee for society.

It is secure and also provides the basis for the realization of other concepts. Proper understanding of the hierarchy and position of each concept is a kind of closeness and proper relationship between theoretical and practical wisdom. In this regard, if we believe in the hierarchy between mediating concepts. Freedom is at the peak of this process. Freedom is the main point of man's descent from heaven and at the same time the main possibility of man's return to heaven (Mirahmadi, 2012). 
Saeed Ayoobi Yazdi, Seyed Mehdi Mansouri y Mohammad Reza Rahmat

\section{Existence of value system}

In Islam, we should not look at the elements of religious interests and values independently or as an island, but it should be noted that the set of interests and values in a systematic, logical, and coordinated system and in a meaningful relationship and together form the Islamic system. And in fact, the constituent elements and basic concepts that make up Islamic knowledge are placed together in regular and codified thoughts and find meaning. This systemic approach will be more comprehensive than the traditional view and will be able to respond more to the incidents (Mirahmadi, 2012).

Security and freedom are not considered as single and independent values, but in various forms are prerequisite and not sufficient conditions for the realization of the desired political system in Islam. Therefore, other superior Islamic ideals in Islam should not be sacrificed for security. At the same time, the existence of a system of other values in Islam is considered, which in a coordinated system and in a completely interrelated manner, provide the conditions for achieving the desired goal. Justice and dignity are among these values that will be present together as measure to measure their accuracy throughout the rout.

It is based on the necessary minimum, middle and maximum relationship between security and freedom in Islam.

\subsection{Minimal relationship}

This ratio depends on the political and social conditions in which Muslims live, in which no social group is dominant in terms of population. Due to the existence of safe contexts, individual freedoms are possible, and it is in the light of these freedoms that Muslims can achieve their faith and religious goals in a minimal and individual way. In this regard, the basis of action is based on the law and based on equality and freedom and is similar to the teachings of the Republicans on freedom in which not only do people not harm each other (security) and provide them with the opportunity to live freely and participate.

In this regard, while respecting the "specific" approaches to social construction, the government domain is "neutral" and the public arena is based on "public good".

In such a society, there is a field of cultural tolerance, and no group attacks the other and they all live together according to the law and framework. The bond of Muslims in this system is due to the provision of appropriate security and freedom for holding religious ceremonies, as well as the possibility of trying to prevent the approval of anti-Islamic laws. This provides the minimum living conditions for Muslims. 
In this situation, Muslims must reach a kind of compromise with other groups to maintain security, justice, and freedom in terms of political and social construction. Also, the Muslim community in this type of society is confined to a specific area and with specific actions. There is no legal solution to the conflict between the social issues of Muslims and non-Muslims.

Therefore, the minimum ratio between security and freedom is necessary only for a suitable individual life and may not necessarily provide a life in accordance with Islamic teachings. In this space, criminal policy is present only in individual areas and will not be able to be present in society. However, it must be emphasized that it provides minimal security and freedom, and that such a society is better than an insecure, unjust, and authoritarian one.

\subsection{Intermediate Relationship}

This relationship, which is the responsibility of the government, is to provide the basic interests of the right to life, the right to faith, the right to reason, etc., from the duties and responsibilities of the government and from the rights of the people.

In this theory, there is a constructive interaction between security and freedom. "Purposeful" and "limited" participation of the people should be used as an effective source of security alongside the government; this action makes it possible to lose the originality of security or freedom of subject matter and somehow be able to combine between the two.

Belonging to these materials guarantees the fundamental freedoms of individuals. Here, security and freedom from the form of public good that was discussed in the previous relationship can be pursued as a duty of the government and the fundamental right of the people, and the legitimacy of the Islamic government in pursuing the five basic interests of human life.

Here, sovereignty is a means to ensure the security and freedom of the Muslim community, and the main sovereignty of God, therefore, is the original issue of security and freedom of individuals; Man, as the divine caliph on earth, must be the trustee of the government to achieve the divine goals. This makes Muslims wary of tyranny and arrogance but ensuring security and individual freedoms will require the existence and maintenance of the security of the Islamic government.

If these things are achieved in the Islamic government, the Islamic society will move in the direction of its sublime goals, namely faith in God and happiness, because if the government provides basic human rights and freedoms, the ground will be prepared for the realization of good and authority for Muslims. Human beings, due to their rationality and responsibility, as well as the existence of a suitable social context, will know the God better. 
This particular social context can only be ignored if there is some kind of reform. Correction or the process of assessing expediency refers to a good or a harm that is in line with the purposes of the Shari'a and the requirements of common sense. According to Al-Ghazali, the purposes of Shari'a are to protect the five intrinsic values, namely religion, modesty, intellect, generation, and property. Any action that guarantees these values is in the scope of expediency and anything that violates them is corrupt, and stopping the latter is also a useful expediency (Kamali, 2002).

The difference between this system and the first type is that these fundamental rights and freedoms are inferred from the teachings of the Shari'a; Humans have a role to play in legislation; the system seeks to implement the teachings of Sharia. Unlike the first type, subjects and laws cannot go beyond the religious realm, so they are considered religious. In other words, the measure is Shari'a, but the public space is free to study the subject (Nezhad, 2020).

\subsection{Maximum Relationship}

The main relationship that can be considered between security and freedom, then, is the maximum ratio between them. In the first relation, the instant purpose of this system of human life was defined in agreement with each other and away from any oppression and in the personal realm of individuals. In the second ratio, based on the religious teachings of the Islamic government, it acts to establish a relationship between security and freedom and to provide basic interests. In this system, security and freedom are the same. In the third relation, which is the maximum relationship between security and freedom, security and freedom are defined in another way.

Security is not only the protection of the five interests, but also religious and faith security (Akhoondi, 2005), and freedom is considered here in the form of complete freedom. Because the little basis of the movement of the world is towards monotheism. Criteria for assessing security and freedom should also be drawn based on the trend of short life. This makes human beings know and evaluate each other's performance with a more appropriate criterion.

In this process, security and freedom are not limited to the material world, but also include the hereafter of human beings. so there is no substantive conflict between them in the material and spiritual worlds, although we may encounter conflict in their operational realization. Therefore, it is justifiable that during jihad, some people have to sacrifice their lives for the safety of other people. Therefore, the practical goal is to realize the good life of this world and the hereafter and the mutual happiness of the individual and society in the light of religious and intellectual teachings. 
This new structure can be offered in three forms: First, in the form of free will, in which man can freely choose his religion (No reluctance in religion) based on his rationality and responsibility. This aspect, the aspect of goodness, is defined in the Islamic system and in individual domain. The second form, is the realm of right, in which security and freedom emerge in the collective realm in a participatory manner. The third form is the realm of purpose, which is the security of faith, and freedom means submission and servitude. The concepts of security and freedom at this stage go beyond the means of good and right and approach the realm of duty. These forms show that Islam, despite being a perfect religion, but at the same time, the interference and conflict between external authority and freedom and duty in Islam will disrupt this good system.

In this sense, security and freedom have a definite purpose and freedom is a kind of servitude. Therefore, in Islam, freedom is associated with submission and servitude, and this submission, which is accompanied by the voluntary acceptance of religious restrictions, is accompanied by an apparent reduction of freedom, followed by security.

In the same way, when man enslaves God, he not only achieves more complete security and freedom in the shadow of the law, but also frees himself from belonging to anything other than God. Therefore, in this situation, there is no paradox between freedom and servitude, and in fact submission and servitude are the same as freedom. Another important point is that these three realms of authority, right and duty in Islam should not interfere with each other. The domain of authority is a personal matter and in the social domain it does not function properly, and its actions cause the imposition of opinions and sometimes the violation of the rights of others. Issues in this realm include freedom of choice, freedom of authority, freedom of personal decision, and freedom of creation (Govich, 1974).

This domain is related to the individual realm of individuals and cannot be extended to the public domain, and therefore entering into social domain in this domain restricts the right of human beings to privacy and the private domain of individuals. At the same time, the domain of authority that is attached to the personal realm is different from the domain of right and the domain of duty. Since the social realm is the realm of right, it cannot be described on the basis of good and free will, but it is described on the basis of duty, because right and duty are related to each other.

It is this heterogeneity that, if the domain of individual authority increase in relation to the responsibility of the origins of primordial theories, will lead to improper justifications in the domination of security and freedom over each other. Human beings are inherently equal, but the responsibility of individuals is also defined in terms of the extent to which they enjoy social rights such as the right to sovereignty. 
Thus, the social domain is the domain of the reciprocal relationship of rights and responsibilities, not their one-way relationship. Just as the individual has the right and responsibility, so does the ruler have the right and responsibility. Failure to combine rights and duties will result in nothing but rebellion. Finally, the realm of faith in God is the realm of education and servitude, and indeed the realm of duty.

The scope of the task will be due to the interrelationship with the field of rights and comprehensive authority of the minimal and intermediate systems. The Islamic system has succeeded only when it can establish a logical proportion between the three aforementioned components, which is authority, right and duty, and when this proportion is not achieved and in other words, an imbalance (departure of objects from their positions) occurs, it affects the good system, and we move away from the desired system as much.

\section{Formal rules of temporary deprivation of the right to liberty and security}

As stated in the previous section, according to international human rights instruments, the deprivation of the right to liberty and security of persons must necessarily be carried out in accordance with the law, and in addition to the legal authorization for deprivation of the right to liberty and security of individuals, it is necessary that this matter be based on the observance of formal rules and regulations, including the deprivation of the mentioned right by the judiciary and its limitation. Individuals' right to liberty should be exercised in the case of illegal extradition, which is also recognized in domestic law. Therefore, we will discuss the mentioned issues in order to clarify the degree of compliance of these laws with the international human rights instruments in this field.

\subsection{The necessity of justifying and substantiating the temporary deprivation of liberty}

During the preliminary investigation, the judicial authority who has sought evidence of the crime from the person being prosecuted, will limit, or deprive the freedom of the human in accordance with the requirements of the society and, contrary to the presumption of innocence. This decision of the investigator is made on the basis of quia timet bill, the subject of which may be a financial obligation, such as the obligation to appear with the determination of the obligation; Moral commitment, such as the obligation to attend as promised; The power of distress, such as collateral or sponsorship; Restriction of travel, such as the obligation not to leave the jurisdiction; Finally, the most severe form of deprivation of liberty is called detention or power of distress. 
Deprivation of the right to liberty of a defendant is an issue which has been seriously criticized by jurists and the advanced rules of criminal procedure; Because non-observance of the right to liberty and security of person and non-observance of the equal rights of the parties to a criminal case - what is known as the equality of arms - infringes on the right of the accused to defend himself; and in this way only the rights and freedoms of the accused are lost; especially that the probability of judicial errors due to incomplete information of the decision-making authority at this time is much higher than the judicial stage and pronouncement (Khaleqieh, 2014).

These issues have caused that governments both domestically and internationally seek to establish rules and regulations that are consistent with their obligations with respect to protection of individual rights and freedoms and the conduct of a fair trial that according to which the reasons for issuing a temporary detention order very limited and in that case, the maximum facilities for providing and guaranteeing the freedoms and preparation and defense of the accused should be provided to him.

For example, clause 2, article 9 of the Covenant on Civil and Political Rights provides: Whoever is arrested must be informed of the reasons for his arrest at the time of his arrest and (must) be informed promptly of any charges against him. Elsewhere, declare the estate duty to bring the suspect to the judiciary as soon as possible and to prohibit his detention during the course of the preliminary investigation and proposed to the extent that is possible to use alternatives actions of temporary detention. For this reason (Ashouri, 2008), the judicial authority should, at the time of the arrest of the accused, give detailed reasons as to why there are not enough alternatives to keep the accused at his disposal, and the detention of the accused should be considered as the only possible means (Ashouri, 2008).

On this basis, and with respect to guarantee of the rights of citizens as much as possible and the prevention of arbitrary detention and the protection of the right to liberty and personal security of individuals, the Iranian legislature has always obliged the detention authorities to mention the reasons for detaining and justifying the privation of liberty of citizen.

In the domestic law of Iran, in addition to Article 32 of the Constitution of the Islamic Republic of Iran, which regulates the prohibition of illegal detention. Article 437 of Judicial Procedure Code of the General and Revolutionary Couzrts has been approved in criminal matters approved in 1999 has considered the necessity of proving by reasoning and legal approve of having temporary detention writ.

Accordingly, "the investigating judicial authority shall, in the event of an attempt to secure a criminal conviction, have sufficient evidence for the occurrence of the crime and its attribution to the accused”. 
Clause 1 of the Law on Respect for Legitimate Freedoms and Citizenship Rights 5, approved on 04.05.2004, also emphasizes the rationale and documentation of the deprivation of the right to liberty of individuals. And other provisions of the law regarding the provision of criminal justice goals and the achievement of human rights standards and norms, including the prevention of arbitrary detention and avoidance of unnecessary detention of individuals and the reduction of the issuance of detention and protection of the right to liberty and security of individual is of very importance. New Code of Criminal Procedure 2013 has also considered the same provisions of the previous laws regarding the necessity of justification of detention.

Subject to the provisions of these articles, Iranian law on the need to justify a temporary detention writ is totally in accordance with international human rights law, in particular Article 9 the International Covenant on Civil and Political Rights, which is fully applicable in the civil and political law of the country.

\subsection{Limiting the period of detention and temporary deprivation of liberty}

One of the issues related to temporary detention, which has attracted the attention of jurists, has long been that changing its title from detention pending trial to temporary detention under French July law of 1970 also confirms the temporary and limited nature of this provision. However, when the period of detention is not provided for in the law, the accused, who has been remanded in custody for a period of time, will in practice be imprisoned for a long time due to the high density of the case or the need to complete an investigation. and the detrimental and irreparable effects of its reparation, especially when it becomes apparent that, due to lack of sufficient reasons, it will eventually lead to a confinement prohibitory function or acquittal, or that, if convicted, the defendant is sentenced to less than a term of imprisonment (Khazaei, 1998).

Clause 3, article 9 of the Covenant on Civil and Political Rights provides: "Anyone arrested and/or detained on a criminal charge shall be promptly brought before a judge or other authorized official to be tried and acquitted by a law governing the jurisdiction of the judiciary during the reasonable period" (Khazaei, 1998: 285). Detention and waiting for the trial of individuals should not become a general rule ...”. Article 6 of the European Convention on Human Rights provides: "The detention of the accused shall not exceed a reasonable period of time" (Khazaei, 1998: 285).

It should be noted that the International Covenant on Civil and Political Rights and other human rights instruments do not provide a specific period of detention for the accused, but that the detainee should be released immediately before a judge in a reasonable period. 
Setting a time limit for the detention of individuals is, of course, a matter of expediting the expeditious conduct of the investigation by the investigating authority within the time limit set. Therefore, the creation of a time limit should be short-lived, as it is a matter for the law to detain persons and to detain them in support of individual rights and is considered an important step by the judiciary to prevent long-term detention.

Article 37 of Judicial Procedure Code of the General and Revolutionary Courts in Criminal Affairs, adopted in 1999, stipulates that the status of the detained defendant must be clarified within one month, and he must be released and must be released upon the issuance of an quia timet bill and, if necessary, the quia timet bill shall be renewed, stating the reasons and documents.

The Amendment to the Law on the Establishment of Public Courts and the Revolution approved in 2002, which also entrusted the preliminary investigation of all crimes to the investigator, in this regard, Article "T" Article 3 stipulated that whenever in the crimes in question the jurisdiction of the provincial criminal court is up to four months and in other crimes up to two months due to the issuance of a quia timet bill, the accused is in custody and If the case against him does not lead to a final decision in the court, the authority issuing the contract is obliged to consider or reduce the quia timet bill of the accused.

Unless there are reasons for legal mitigation or justifiable reasons for the survival of the issued quia timet bill, in which case the reasons are maintained and .... "If the detention of the accused continues, the provisions of this paragraph shall be applied every four months or every two months, as the case may be" (Forum, 2006: 290).

Considering the difference in the contents of the preceding articles, it is considered that within the time limit, temporary detention and explicit paragraph $(\mathrm{T})$ of the above-mentioned law which states: “... The accused has been detained and his case file has not led to a final decision in court" (Forum, 2006: 290), it should have been determined that if a temporary detention order is issued in court, the court was obliged to comply with the provisions of Article 34 mentioned above, and if this decision is issued in the prosecutor's office, the interrogator should comply with the provisions of clause ( $\mathrm{T}$ ) article 3 of the mentioned law for the investigator and prosecutor.

The new Criminal Procedure Code has adopted in 2003 a single procedure in the courts and tribunals, and in Article 7242, the Iranian legislature, in addition to the legal requirement of temporary detention and its reasonableness, the minimum length of detention of accused in proportion to the current law in major offenses reduce from two months to one months. And the maximum time in which the accused is detained for the crimes of deprivation of life and other crimes is also determined by the 
Saeed Ayoobi Yazdi, Seyed Mehdi Mansouri y Mohammad Reza Rahmat

observance of the rights of the accused and a fair trial and the limitation of the period of deprivation of liberty of accused and compliance with international human rights instruments is also a key step in this regard (Forum, 2006).

\subsubsection{The right to request the review of the legality of the temporary deprivation of liberty and the request for liberty}

Since the principle of liberty of the accused while conducting preliminary research is based on sovereignty the principle of innocence and deprivation of liberty is contrary to the principle and only in exceptional cases may be the subject of the verdict and that inevitable judicial errors are reminiscent of the bitter experiences of depriving innocent people of their liberty.

The advanced rules of criminal procedure code, contrary to what has prevailed in the past, in such a way that only the judicial authority issuing the temporary detention order or his successors could reduce, convert or cancel temporary detention order. The right of the defendant to appeal the judicial decision has been accepted by the decision-making authority, if necessary, with the exercise of judicial control and two-level trial.

Clause 3 of Article 3 of the International Covenant on Civil and Political Rights recognizes this right: Anyone deprived of liberty as a result of arrest or detention have the right to demand justice and in order for the court to declare without delay that the detention is lawful and, if it is illegal to detain him, to order his release.

Apparently, the basis for accepting this right is to reduce judicial errors and, as a result, to limit any further effects of an act is in contrary to the principle of the acquittal of the accused in the detention of the accused.

Cancel of detain writ or convert him at the request of the accused had long been accepted in clause 4 of Article 38 of Criminal Procedure Code of Iran, but with the approval of Law on the Establishment of Public and Revolutionary Courts approved in 1994, the right to appeal against the detention was revoked pursuant to paragraph (b) of Article 19 of the said law that considered as infringes on the rights and freedoms of individual of accused and violate the country's international commitments in terms of justice processing and granting the right to appeal to the accused and followed the protests of lawyers and finally by approval Law on the Rules of Procedure of Public Courts and the Revolution approved in 1999 and accordance with Article 33 of this law, again the writ of temporary detain was declared admissible in the provincial court of appeal. Pursuant to this article, "... the deadline for appeal is 10 days and the competent court will consider the request of the accused out of turn". If the appellate court finds the defendant's objection hearable terminate the temporary detention writ 
and returns the case to the issuing court in order to obtain appropriate security.

Another provision that was considered in the law to guarantee the rights of the accused and to prevent the deprivation of liberty of individual in violation of the law was the need to obtain the approval of the head of the district jurisdiction or his deputy if the judge had ordered it.

In the Law Amending the Law on the Establishment of Public Courts and the Revolution approved in 2002, the legislature adopted a more appropriate mechanism for judicial control and objection to temporary detention and did consider some duties for issuing authorities. In Clause (H) of Article 3 of the mentioned law, the investigator who has the right to issue a temporary detention writ for the accused, must be approved by the prosecutor if a decision is issued by him, and if the reason for detention come to an end, removing the detention must be by agreement of prosecutor. also in this clause, the right of the accused to request the removal of his detention if the reason for his removal was removed has been recognized.

Clause (T) of Article 3 of the said law the issuing authority shall also temporarily suspend if the case does not lead to a final decision in the prosecutor's office, In the crimes subject to the jurisdiction of the criminal court of the province up to four months and in other crimes up to two months, in relation to the mitigation of the quia timet bill of the accused; Unless there are legal reasons or a valid reason for the survival of the issued quia timet bill which in this case by mentioning them the writ will be retained and in this case the accused has the right to appeal against this decision within 10 days from the date of notification to the local or revolutionary court, as the case may be.

As is clear from the text of paragraphs $(\mathrm{H})$ and $(\mathrm{T})$, the Iranian legislature to guarantee the right to object of the defendant to temporary detention in addition to the "right" to object to the "issuance" and "continuation" of the detention write that recognized for defendant. "It was also an 'obligation' for the issuing authority to review its contract at regular intervals".

Criminal Procedure Code of 2013 in article 10241 in protest of the detention order, has accepted almost the same provisions of the previous laws, and in Article 242, has also recognized the right of the accused to object to the renewal and maintenance of the temporary detention order after two months in serious crimes and one month in other crimes, within 10 days from the date of notification in the competent court.

Article 244 of the said law and note 1 of it also recognizes the right to request a reduction of security even after issuance of indictment only once and the court is obliged to hear the sentence even if it wants to plead, and according to Article 245, the court is obliged to consider the defendant's objection in an extraordinary time. 
Pursuant to the above-mentioned articles of Judicial Procedure of the Public and Revolutionary Courts Code in 1999 and the Law on Amending the Law on the Establishment of General and Revolutionary Courts approved in 2001, and Code of Criminal Procedure approved in 2013, It is clear that Iranian law on the recognition and enforcement of the right to object to the provisional deprivation of liberty is explicitly stated in accordance with international human rights instruments, in particular Article 4 of the article 9 International Covenant on Civil and Political Rights and the laws of the country in this field do not have ambiguity and problems.

\section{Conclusion}

In the present study, an attempt was made to discuss the issue of the relationship between the right to security and the right to liberty in Islam and the formal regulations for the deprivation of these rights in Iran. In this regard, after examining the concept of these two rights and discussing the challenges related to their nature, we conduct research and criticize the relationship between these rights in Islam.

In the present article, we have dealt with three types of relations between freedom and security, and it was said that there are three types of structures, minimum, intermediate and maximum in Islam, which indicate the correspondence between security and freedom in Islam and is of great importance. And if there is not possibility of maximum in a situation, Islam has made it possible for Muslims to build other structures, and it is not necessary to abandon one ideal in favor of another.

According to this, we examined the formal provisions of Iranian criminal law from the perspective of the situation of deprivation of these rights. The results showed that according to the right to liberty and security of individual, all persons should always have the right to liberty, and the deprivation of liberty of persons should be exceptional. This is recognized in the Constitution of the Islamic Republic of Iran in accordance with international human rights instruments. Deprivation of liberty and personal security of individuals should be done only on the basis of law and the order of a judicial authority and as an inevitable necessity.

This is recognized in the basic and ordinary laws of Iran, and although it has its defects, the approved criminal procedure law has removed most of the objections raised in the previous law. The deprivation of liberty exercised by the judicial authorities must be reasoned and justified, and the legal document and the reasons for its issuance must be stated. According to the right to liberty and security of individual, it is necessary to deprive the individual of liberty exercised in accordance with the law must be limited to a certain period of time and a fair trial of the arrested persons should be 
held as soon as possible.

In Iranian law, Civil Procedure Code and the Revolution in Criminal Affairs and the Law Amending the Law on the Establishment of Public Courts and the Revolution recognized this right. However, there were ambiguities that the adopted Code of Criminal Procedure, in addition to eliminating, also reduced the period of temporary deprivation of liberty. On the other hand, according to the principle of deprivation of liberty, individuals have the right to object to their arrest or detention. Iranian law explicitly recognizes this principle. Under the right to liberty and security of law, individuals have the right to seek their liberty on the ground that their deprivation of liberty is illegal. Iranian law also explicitly recognizes this principle.

\section{Bibliographic References}

AKHOONDI, Mahmoud. 2005. Criminal Procedure Code. Mizan Publishing. Tehran, Iran.

ASHOURI, Mohammad. 2008. Criminal Justice. Mizan Publishing. Tehran, Iran.

BUZAN, Bari; WEAVER, Eli. 2007. "A New Framework for Security Analysis" In: Institute for Strategic Studies Publications. Vol. 15, No. 2, pp. 79-87.

COPLESTON, Frederick. 2013. From Bentham to Russell, Translated by: Bahauddin Khorramshahi. Soroush Publishing Company. Tehran, Iran.

COPLESTON, Frederick. 2016. History of Philosophy, from Wolf to Kant, translated by Ismail Saadat and Manouchehr Bozorgmehr. Soroush Publishing Company. Tehran, Iran.

DINARVAND, Ali Abas; AZIN, Ahmad; GOLSHANI, Alireza. 2021. "To Study the Formation and Increase of Social Capital in Islamic Republic of Iran" In: Cuestiones Políticas. Vol. 39, No. 69, pp. 852-869.

FOROUZAN FAR, Leila. 2021. "Iran's criminal policy towards money laundering in the country's banking system” In: Cuestiones Políticas. Vol. 39, No. 69, pp. 344-36o.

FORUM, Eric. 2006. Escape from Freedom, translated by Ezatollah Fooladvand. Morvarid Publications. Tehran, Iran.

FRIEDMAN, Lawrence. 1999. "The concept of security, in a collection of selected political articles" In: The Research Institute for Strategic Studies Publications of the Research Institute for Strategic Studies. Vol. 32, No. 6, pp. 246-255. 
GOVICH, Georges. 1974. Social Force and Human Freedom A step forward in the field of sociological study of the struggles and advances of freedom. translated by Hassan Habibi. Tehran, Iran.

HATZENBERGER, Antoine. 2007. Azadi, translated by Abbas Bagheri. Alam Publishing. Tehran, Iran.

KAMALI, Mohammad Hashem. 2002. Freedom of Expression in Islam (collection of articles), written, selected and translated by Mohammad Saeed Hanaei Kashani. Ode. Tehran, Iran.

KHALEQIEH, Ali. 2014. Criminal Procedure Code. Institute of Legal Studies and Research, Shahr-e-Danesh. Tehran, Iran.

KHAZAEI, Manutschehr. 1998. Collection of articles on the criminal process. Ganje Danesh Publications. Tehran, Iran.

MIRAHMADI, Mansour. 2012. "Political Freedom in the Holy Quran" In: Fourth Strategic Meeting on Freedom. Vol. 9, No. 4, pp. 113-120.

NEZHAD, Hedayatollah; HAZERI, Javad. 2020. "Constituent elements of prohibited vertical agreements in the competition law of Iran and the European Union” In: Cuestiones Políticas. Vol. 38, No. 67, pp. 378-395.

SHAKERI, Reza. 2006. "Power as Security; Review of Modern Political Theory" In: Quarterly Journal of Strategic Studies. Vol. 11, No. 3, pp. 748-760.

SOROUSH, Abdul Karim. 1992. "Reason and Freedom” In: Kian Magazine. Vol. 17, No. 2, pp. 59-86.

SOROUSH, Abdul Karim. 2009. Tradition and Secularism Collection of Discourses. Sarat Publications. Tehran, Iran. 

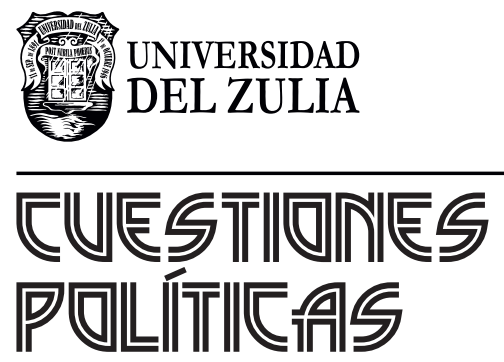

Vol. 39 N $^{\circ} 71$

Esta revista fue editada en formato digital y publicada en diciembre de 2021, por el Fondo Editorial Serbiluz, Universidad del Zulia. Maracaibo-Venezuela 